\title{
Unacylated ghrelin and obestatin in pediatric CKD: are they important in protein energy wasting?
}

\author{
Zhen Wang $^{1,2} \cdot$ Eduardo A. Oliveira $^{1,3} \cdot$ Robert H. Mak $^{1}$ (1)
}

Received: 3 December 2017 / Revised: 10 January 2018 / Accepted: 10 January 2018 / Published online: 16 February 2018

(C) IPNA 2018

\section{CKD and protein energy wasting}

According to the International Society of Renal Nutrition and Metabolism (ISRNM), protein energy wasting (PEW) in chronic kidney disease (CKD) is defined as a "state of nutritional and metabolic derangements characterized by simultaneous loss of systematic body protein and energy stores, leading to loss of muscle and fat mass and, ultimately cachexia" [1]. PEW describes a pathological state characterized by anorexia and a high metabolic rate in the face of a negative energy balance resulting in abnormal body composition of decreased muscle mass, with or without decreased fat [2]. CKD staging has been associated with PEW prevalence. In adults with moderate to severe CKD, PEW prevalence is between 18 and $48 \%$, going up to $75 \%$ in patients on dialysis [3, 4]. Children with CKD are also at risk for PEW. PEW prevalence is difficult to ascertain since there is no consensus for its definition and assessment. In this regard, of particular interest, Abraham et al. [5] using data from 528 children enrolled in the Chronic Kidney Disease in Children (CKiD) study, have shown that PEW prevalence ranged from 7 to $20 \%$ depending on the definitions used.

A number of epidemiological and cohort studies have demonstrated the association of PEW with high morbimortality and low quality of life [6]. On the other hand, the association between this wasting syndrome and adverse outcomes in

Robert H. Mak

romak@ucsd.edu

1 Division of Pediatric Nephrology, Rady Children's Hospital San Diego, University of California San Diego, 9500 Gilman Drive, MC 0630, La Jolla, CA 92093-0630, USA

2 Department of Pediatrics, Shanghai General Hospital, Shanghai Jiaotong University, Shanghai, China

3 Pediatric Nephro-Urology Division, Department of Pediatrics, School of Medicine, Federal University of Minas Gerais (UFMG), Belo Horizonte, MG, Brazil children with CKD has not been established, again mainly due to the absence of consensus regarding the diagnosis of these nutritional disorders.

The pathophysiology of PEW/cachexia syndrome in CKD is multifactorial. "The proposed criteria to establish the diagnosis of PEW includes four categories: (1) biochemical indexes; (2) body weight parameters, including reduced body fat and weight loss; (3) reduced muscle mass; (4) low protein/energy intake" [2]. Anorexia is included as a criterion for cachexia [7], while poor protein/energy intake is a criterion for PEW [1]. Anorexia, defined as the loss of appetite and early satiety, is prevalent in adults and pediatric CKD patients [8]. Anorexia in these patients is multifactorial, including an abnormal sense of taste, abnormal gastric emptying, and increased circulatory inflammatory cytokines [2,9]. Perturbations in anorexigenic/ orexigenic hormones, including leptin, ghrelin, and obestatin, may also be important [10].

\section{Ghrelin and obestatin}

Ghrelin is synthesized and secreted predominantly by the stomach, but also by many other tissues. It has hormonal as well as autocrine/paracrine effects [11]. The GHRL gene encodes human ghrelin. Transcription produces a prepro-peptide that undergoes acylation by the ghrelin O-acyltransferase (GOAT) enzyme and subsequent modification by convertases, resulting in acylated ghrelin (AG) or unacylated ghrelin (UAG) [12]. Recent investigations show that prepro-ghrelin mRNA may also be involved in the synthesis of obestatin, whose physiological effects diverge from those of ghrelin [13].

In humans, circulating ghrelin consists of UAG (>90\%), $\mathrm{AG}$, and C-ghrelin. The acylated form of ghrelin has been considered to be the primary appetite-stimulating hormone while UAG induces negative energy balance [14]. There is evidence from rodent studies that obestatin is anorexigenic, by inducing anorexia and weight loss as well as slowing peristalsis. Therefore, two peptides encoded by the same 
gene exert contrasting effects on energy homeostasis via different receptors [13].

\section{Ghrelin, obestatin and CKD}

Human data on ghrelin and CKD-PEW are inconclusive to date. Although ghrelin is degraded in the kidney, its levels are not uniformly increased in CKD patients [15]. Some studies with dialysis patients have demonstrated elevated ghrelin levels, whereas other studies have shown normal or even low ghrelin levels in CKD patients [16, 17]. A possible explanation for these seemingly contradicting findings is that only UAG levels were elevated in the CKD patients. For example, Gupta et al. [18] analyzed AG and UAG levels in 51 CKD and 15 hemodialysis (HD) patients using two separate site-specific assays for these hormones. The results demonstrated that UAG levels increased with declining estimated glomerular filtration rate (eGFR), whereas AG levels remained unchanged. In particular, increased UAG concentrations inversely correlated with eGFR with high accuracy.

In their recently published article in Pediatric Nephrology, Monzani and colleagues measured both UAG and obestatin and investigated their efficacy as potential biomarkers of PEW in CKD children [19]. Measurements of ghrelin (acylated and unacylated) and obestatin were compared between 110 children with CKD (42 on conservative treatment, 20 on HD, and 48 transplantation recipients) and 43 controls. The results showed that while AG concentrations did not differ between the patients and controls, UAG concentrations was significantly higher in the patients, notably in CKD-HD patients. Likewise, obestatin concentrations were significantly higher in CKD-HD patients than in the control subjects and in nondialysis CKD patients.

Monzani et al.'s study [19] provides some novel information concerning the possible role of the hormones that partially regulate food intake and energy homeostasis in CKD children. We believe that the special interest of this study lies in the fact that UAG, AG, and obestatin concentrations were, for the first time, measured separately in a considerable cohort of pediatric patients with CKD. As a result, the approach of these authors allowed confirmation of the hypothesis that UAG accounts for the excess of circulating ghrelin in pediatric CKD patients. In addition, there was an inverse correlation of UAG with eGFR, urea, body mass index (BMI)-standard deviation score (SDS), weight-SDS, and percentage fat-free mass, and a direct correlation of UAG with creatinine and urea as well as percentage fat-free mass. There was an inverse correlation of obestatin with eGFR and weight-SDS and a direct correlation with creatinine and urea. The authors were careful to account for possible confounding variables, such as gender, age, puberty, and BMI-SDS. Therefore, they were able to draw the conclusion that UAG and obestatin seem to be promising inverse indicators of nutritional status in children with CKD.

Regarding the treatment of PEW syndrome, it is important to point out the possible clinical implications of the findings of Monzani and colleagues [19]. Evidence to date has evaluated the orexigenic impact of AG pharmacology in patients with chronic disorders [20]. For example, a number of experimental studies have corroborated the potential of ghrelin and ghrelin analogues to increase food intake and body weight gain in cachectic patients with heart failure [21], CKD [22], and cancer [23]. Based on these positive preliminary results, human trials have further demonstrated enhancements of appetite and body mass with ghrelin analogue treatment in patients with anorexia nervosa [24], renal failure [25], heart failure [26], chronic obstructive pulmonary disease [27], and cancer [28]. However, the long-term safety and efficacy of ghrelin for the treatment of cachexia associated with chronic conditions has not been systematically investigated. Interestingly, in light of their findings, Monzani et al. [19] argue that a fundamental point in treatment of PEW syndrome in pediatric end-stage renal disease patients "should be the effective removal of anorexigenic molecules like UAG and obestatin, rather than the administration of AG". This is an interesting though still speculative hypothesis that needs to be addressed by future studies.

\section{Conclusion}

The study by Monzani et al. [19] undoubtedly contributes to our knowledge concerning the peptides involved in pediatric $\mathrm{CKD}$ and $\mathrm{PEW}$. The authors provide important data regarding UAG, AG, and obestatin concentrations in a considerable cohort of pediatric CKD patients, with important novel implications for biomarker discovery and therapeutic strategy. Further investigations are needed on the role of these hormones in the pathophysiology and treatment of complex nutritional disorders in pediatric CKD.

Acknowledgements Preparation of this commentary was supported by grants from the National lnstitutes of Health (NIH) UO I DK03012 to RHM and Shanghai General Hospital Shortage Talents Project to ZW.

\section{Compliance with ethical standards}

Disclosure The authors declare no competing interests.

\section{References}

1. Fouque D, Kalantar-Zadeh K, Kopple J, Cano N, Chauveau P, Cuppari L, Franch H, Guarnieri G, Ikizler TA, Kaysen G, Lindholm B, Massy Z, Mitch W, Pineda E, Stenvinkel P, TrevinoBecerra A, Wanner C (2008) A proposed nomenclature and 
diagnostic criteria for protein-energy wasting in acute and chronic kidney disease. Kidney Int 73:391-398

2. Mak RH, Cheung WW, Zhan JY, Shen Q, Foster BJ (2012) Cachexia and protein-energy wasting in children with chronic kidney disease. Pediatr Nephrol 27:173-181

3. Foucan L, Merault H, Velayoudom-Cephise FL, Larifla L, Alecu C, Ducros J (2015) Impact of protein energy wasting status on survival among afro-Caribbean hemodialysis patients: a 3-year prospective study. Springerplus 4:452

4. Kovesdy CP, Kopple JD, Kalantar-Zadeh K (2013) Management of protein-energy wasting in non-dialysis-dependent chronic kidney disease: reconciling low protein intake with nutritional therapy. Am J Clin Nutr 97:1163-1177

5. Abraham AG, Mak RH, Mitsnefes M, White C, Moxey-Mims M, Warady B, Furth SL (2014) Protein energy wasting in children with chronic kidney disease. Pediatr Nephrol 29:1231-1238

6. Ahmadi SF, Zahmatkesh G, Ahmadi E, Streja E, Rhee CM, Gillen DL, De Nicola L, Minutolo R, Ricardo AC, Kovesdy CP, KalantarZadeh K (2015) Association of body mass index with clinical outcomes in non-dialysis-dependent chronic kidney disease: a systematic review and meta-analysis. Cardiorenal Med 6:37-49

7. Evans WJ, Morley JE, Argiles J, Bales C, Baracos V, Guttridge D, Jatoi A, Kalantar-Zadeh K, Lochs H, Mantovani G, Marks D, Mitch WE, Muscaritoli M, Najand A, Ponikowski P, Rossi Fanelli F, Schambelan M, Schols A, Schuster M, Thomas D, Wolfe R, Anker SD (2008) Cachexia: a new definition. Clin Nutr 27:793-799

8. Rees L, Jones H (2013) Nutritional management and growth in children with chronic kidney disease. Pediatr Nephrol 28:527-536

9. Cheung WW, Paik KH, Mak RH (2010) Inflammation and cachexia in chronic kidney disease. Pediatr Nephrol 25:711-724

10. Mak RH, Cheung WW (2011) Is ghrelin a biomarker for mortality in end-stage renal disease? Kidney Int 79:697-699

11. Kojima M, Hosoda H, Date Y, Nakazato M, Matsuo H, Kangawa K (1999) Ghrelin is a growth-hormone-releasing acylated peptide from stomach. Nature 402:656-660

12. Takahashi T, Ida T, Sato T, Nakashima Y, Nakamura Y, Tsuji A, Kojima M (2009) Production of n-octanoyl-modified ghrelin in cultured cells requires prohormone processing protease and ghrelin $O$ acyltransferase, as well as $n$-octanoic acid. J Biochem 146:675-682

13. Zhang JV, Ren PG, Avsian-Kretchmer O, Luo CW, Rauch R, Klein C, Hsueh AJ (2005) Obestatin, a peptide encoded by the ghrelin gene, opposes ghrelin's effects on food intake. Science 310:996-999

14. Hosoda H, Kojima M, Matsuo H, Kangawa K (2000) Ghrelin and des-acyl ghrelin: two major forms of rat ghrelin peptide in gastrointestinal tissue. Biochem Biophys Res Commun 279:909-913

15. Cheung WW, Mak RH (2010) Ghrelin in chronic kidney disease. Int J Pept 2010:567343. https://doi.org/10.1155/2010/567343
16. Iglesias P, Diez JJ, Fernandez-Reyes MJ, Codoceo R, AlvarezFidalgo P, Bajo MA, Aguilera A, Selgas R (2006) Serum ghrelin concentrations in patients with chronic renal failure undergoing dialysis. Clin Endocrinol 64:68-73

17. Perez-Fontan M, Cordido F, Rodriguez-Carmona A, Peteiro J, Garcia-Naveiro R, Garcia-Buela J (2004) Plasma ghrelin levels in patients undergoing haemodialysis and peritoneal dialysis. Nephrol Dial Transplant 19:2095-2100

18. Gupta RK, Kuppusamy T, Patrie JT, Gaylinn B, Liu J, Thorner MO, Bolton WK (2013) Association of plasma des-acyl ghrelin levels with CKD. Clin J Am Soc Nephrol 8:1098-1105

19. Monzani A, Perrone M, Prodam F, Moia S, Genoni G, Testa S, Paglialonga F, Rappa A, Bona S, Montini G, Edefonti A (2017) Unacylated ghrelin and obestatin: promising biomarkers of protein energy wasting inchildren with chronic kidney disease. Pediatr Nephrol. https://doi.org/10.1007/s00467-017-3840-z

20. Muller TD, Perez-Tilve D, Tong J, Pfluger PT, Tschop MH (2010) Ghrelin and its potential in the treatment of eating/wasting disorders and cachexia. J Cachexia Sarcopenia Muscle 1:159-167

21. Nagaya N, Kangawa K (2003) Ghrelin, a novel growth hormonereleasing peptide, in the treatment of chronic heart failure. Regul Pept 114:71-77

22. DeBoer MD (2008) Emergence of ghrelin as a treatment for cachexia syndromes. Nutrition 24:806-814

23. Hanada T, Toshinai K, Date Y, Kajimura N, Tsukada T, Hayashi Y, Kangawa K, Nakazato M (2004) Upregulation of ghrelin expression in cachectic nude mice bearing human melanoma cells. Metabolism 53:84-88

24. Hotta M, Ohwada R, Akamizu T, Shibasaki T, Takano K, Kangawa K (2009) Ghrelin increases hunger and food intake in patients with restricting-type anorexia nervosa: a pilot study. Endocr J 56:1119-1128

25. Wynne K, Giannitsopoulou K, Small CJ, Patterson M, Frost G, Ghatei MA, Brown EA, Bloom SR, Choi P (2005) Subcutaneous ghrelin enhances acute food intake in malnourished patients who receive maintenance peritoneal dialysis: a randomized, placebocontrolled trial. J Am Soc Nephrol 16:2111-2118

26. Nagaya N, Moriya J, Yasumura Y, Uematsu M, Ono F, Shimizu W, Ueno K, Kitakaze M, Miyatake K, Kangawa K (2004) Effects of ghrelin administration on left ventricular function, exercise capacity, and muscle wasting in patients with chronic heart failure. Circulation 110:3674-3679

27. Nagaya N, Itoh T, Murakami S, Oya H, Uematsu M, Miyatake K, Kangawa K (2005) Treatment of cachexia with ghrelin in patients with COPD. Chest 128:1187-1193

28. Temel JS, Abernethy AP, Currow DC, Friend J, Duus EM, Yan Y, Fearon $\mathrm{KC}$ (2016) Anamorelin in patients with non-small-cell lung cancer and cachexia(ROMANA 1 and ROMANA2): results from two randomised, double-blind, phase 3 trials. Lancet Oncol 17:519-531 